\title{
ART SUBJECTS IN NATIONAL CURRICULA - IDEAS FOR FUTURE DEVELOPMENTS IN GENERAL EDUCATION
}

\author{
Anu Sepp \\ Estonian Academy of Music and Theatre, Estonia \\ Urve Läänemets \\ Estonian Academy of Music and Theatre, Estonia \\ Katrin Kalamees-Ruubel \\ Estonian Academy of Music and Theatre, Estonia \\ Kristi Kiilu \\ Estonian Academy of Music and Theatre, Estonia
}

\begin{abstract}
International trends of globalisation, changing learning environments as well as particular socio-cultural contexts and educational policy making are constantly shaping selection of the content for national curricula (NC) of general comprehensive schools. Art subjects (music, literature and art education) have been compulsory elements in Estonian NC for a century already making a significant contribution to identity and personality development of all population. Traditionally, learning art subjects has been well supported by extra-curricular activities or hidden curriculum so far. Today, primarily due to changing cultures and new values, learning motivation and decline of reading and expressive skills of students have become an issue. A pilot research (students' essays, $n=367$ ) was carried out in Estonian general comprehensive basic schools (level 3, students aged 13-16) in 2016 with the aim to specify how students perceive the role and meaning of art subjects in their life. The students' interesting ideas and presented opinions deserve attention when designing syllabi in NCs as well as supportive learning environments for both formal and informal learning activities. Accordingly, an increasing role of art subjects in future curricula should be considered as integrative, balancing and enriching tools for socialization of each individual. Awareness of arts has the potential to contribute to cultural sensitivity and understanding the meta-skills for future lifelong learning and sustainable developments.
\end{abstract}

Keywords: art subjects, national curricula, integrated social skills, expressive skills and cultural identity.

\section{Introduction}

Organizing curriculum change (OCC) has become a central issue in several academic publications. European Journal of Curriculum studies has discussed curriculum policy-making (Autio, 2015), specification of curriculum content

(C) Rēzeknes Tehnologiju akadèmija, 2017 http://dx.doi.org/10.17770/sie2017vol2.2441 
(Laanemets \& Kalamees, 2014), standards, expected students' performance, and regulations (Scott, 2014, Salminen \& Annevirta, 2016). American Sociological Review has also made available earlier research characterising national curricula (NC) for public education by the regions of the world analysing the representation of school subjects (the so-called „knowledge for the masses“, see Benavot, Cha et al. (1991). The Journal of Curriculum Studies has dedicated the whole final issue on the state based curriculum making, comparing different developments in different countries , e.g. Sivesind and Westbury (2016 a, 2016 b, 2016 c), Westbury (2016 d), Rosemund (2016). The 21st century educationists are facing again the need to discuss the selection of the content for learning after a long period of being focused on methods, testing and other issues related primarily to the process of learning. Comprehension of the time as a non-renewable resource that is to be devoted to learning particular subjects representing specific fields of human experience/civilisation has led to OCC in diverse versions of decision-taking in different countries.

Considering the NC for different types and levels of education, the NCs for general education deserve particular attention, as these documents specifying the content for learning and its organization for general comprehensive schools, are meant for educating the whole population. NCs have to be based on recognised needs for future, and ideologies, specified on values accepted as foundations for development of individual and collective identities preserving cohesion and sustainability of a culture and statehood. However, the process of curriculum making requires its management, especially considering its legitimacy, professional quality of results as well as involvement of professional curriculum specialists and different stakeholders representing diverse social interest groups (Sivesind \& Westbury, 2016c: 773). Understandably, any educational reform in the field of curriculum development requires informed decision-making, and its writers have to consider the earlier NCs in their specific contexts, but not only. Pasi Sahlberg, a recognised Finnish education expert has aptly described their highly complicated task when setting the learning agenda and recommended to respect the past, lead the present and secure the future, which is also the title of a forthcoming conference in 2017 in Sydney (http://www.acel.org.au/acel/ ACELWEB/Events/2017/Conference).

\section{The research problem}

The problem for initiating the present study appeared considering the task for OCC issued by the Estonian ministry of education and research (2016) caused by dissatisfaction expressed in media with students' decreasing cultural horizons and inability to transform internal knowledge into performative knowledge. It has become the main issue considering their decision-making and 
problem-solving skills in everyday life, although there are noble goals manifested in all curricula prioritizing knowledge acquisition and development of critical thinking skills. Despite new supportive learning environments, mainly provided by ICT, academic achievement (especially in sciences) has remained a problem in many European countries and the universities have to think about how to manage, considering highly diverse initial level of student candidates. Accordingly, the content of general education preparing young people for both vocational and higher education has become the issue of debate. Understandably, there are different approaches to curriculum design, including the subjects to be selected for studies and their content providing the acknowledged and accepted values in a society.

Every country has its educational traditions and cultural values, which make organization of curriculum change a highly complicated matter. Any desired change must be provided with sound arguments showing the acknowledged needs for innovation. In Estonia there have been proposals to reduce the students' work overload and the amount of knowledge specified for learning in the NCs for general comprehensive schools (Aaviksoo, 2013). It also means that the role of learning arts has to be specified as well, especially considering the costs involved.

However, art subjects (music, literature and art education) have been compulsory elements in Estonian $\mathrm{NC}$ for a century already, since the establishment of statehood, making a significant contribution to identity and personality development of all population. Traditionally, learning art subjects has been well supported by students' optional extra-curricular activities or hidden curriculum so far (Kalamees-Ruubel \& Laanemets, 2012, p. 216). Today, primarily due to globalisation, changing cultures and new values, learning motivation and decline of reading and expressive skills of students have become an issue and needs new approaches to specification of the list of school subjects, the content for learning as well as organisation of studies, see Kalamees-Ruubel (2014).

\section{Aims and the method used}

The main aim of the study was to specify how students perceive the role and meaning of art subjects in their life. The research group has made an attempt to study students' motivation for learning art subjects under present circumstances. Another aim was to learn about students' comprehension of the value of those skills they could acquire in the lessons of art subjects.

Research data were collected in October and November 2016 at sixteen general comprehensive schools with instruction in the Estonian language (grades 7-9, students aged 13-16). The students ( $\mathrm{n}=367,195$ girls and 172 boys) were 
asked to freely express their opinions in writing by providing answers to two questions: "Why are subjects like literature, music and art education in our school timetable? What have you learnt in these lessons that you consider useful?" The expected length of their answers was up to one A4 page, and the time allotted was one school lesson (45 minutes). The students could use any form of writing - essay, discussion, article, etc.

The data were analysed qualitatively by using content analysis (Cohen, Manion, \& Morrison, 2007) with the conventional approach. Considering the three possibilities of carrying out analysis (conventional, directed and summative) as suggested by Hsieh \& Shannon (2005), the approach used in this research analysis is conventional as the coding categories and sub-categories are derived directly from the text data. The advantage of the conventional approach is that it allows to gain direct information from study participants without imposing preconceived categories or theoretical perspectives, which suits best considering the material collected.

\section{Results and Discussion}

The responses were analysed according to two basic criteria: 1) art subjects are still necessary and meaningful for students, and 2) art subjects are irrelevant and could be excluded from school curricula.

With regard to the answers concerning the relevance of music, art and literature, 95,4\% of the respondents considered them necessary and useful, while $4.6 \%$ disagreed. Because of the complexity of the students' opinions about the three art subjects, although they were generally supportive of Criterion 1 , and the fact that the relevance of the three subjects was rated disproportionately (there were more arguments in support of music and art than literature) and expressed in a diversity of ways, the data had to be analysed further.

The second-level analysis was conducted using sub-criteria developed on the basis of the students' arguments supporting the necessity and relevance of art subjects in their studies. The data and statements in support of the second basic criterion were included in the sub-criteria where possible. The sub-criteria are based on different levels of the students' development: their social and psychological development, cognitive and affective development, as well as their perception of the dynamics of acquiring new knowledge through art subjects. The results of the research were summarised, and an attempt was made to synthesise the students' opinions expressing their comprehension of the role of art subjects in their individual development.

The opinions expressed by the Grade 7 students mainly highlighted the positive development of their knowledge, whereas those in Grades 8 and 9 
considered the influence of art subjects on the development of their personality most meaningful. The positive influence of art subjects on the development of the students' creativity, imagination, and cultural awareness as well as their usefulness as a refreshing break between difficult subjects such as math, sciences, and foreign languages during the long school day was mentioned by students in all the grades participating in the research project. In the following discussion the number of students sharing the same view is given, as well as some of the statements they contributed, the gender of the student (B for boy and $\mathrm{G}$ for girl), and their grade.

With regard to personality development the students wrote most frequently about the opportunity to broaden their cultural horizons and develop their awareness of cultural values (124) e.g., If there were no art education we would not know about important people in earlier times (B8). We gain new experience by reading books, so we do not have to experience it personally (G9). When somebody is talking about these topics, I know what the discussion is about, and what I can contribute (G8), and we acquire new knowledge about cultural artefacts and other useful things (85). One can learn a lot about "old" Estonia (G7). Without literature young people would only be on their smartphones where they cannot broaden their horizons or develop their powers of expression (B9). There were many responses citing opportunities for discovering one's talents, finding a suitable interest, and sometimes even a profession. The responses were most often related to learning music (113): I started singing in a choir in Grade 4 at the invitation of the music teacher, and after we had learnt to play some instruments in our regular music lessons, I decided to go to music school and start learning the cello. Therefore, music lessons help students discover their musical ability and use their talents (G8). If you are not good at maths or sports and you cannot draw, there is a chance that you may have a good singing voice (B8). In addition, opportunities for the development of one's identity, self-actualisation, and discovering oneself were mentioned.

With regard to the development of students' social skills the respondents highlighted improvement in their powers of expression in order to be able to participate in discussions (109): The ability to use words properly is essential if you want to get a good job in the future (G9). I believe that if there were no literature lessons, people would have a poor vocabulary, and might even be considered illiterate (B9). Learning these subjects can give you the freedom to be who you really are. Things are different for everyone. We cannot sing using the same voice, we cannot write exactly the same essays, or draw exactly the same picture. These lessons give us courage to dare to be different from others (G8). Many enjoyed the opportunity to sing together (101): Singing together makes us happy (G7). Singing together unites the whole class into one 
team (G9). The potential of art subjects to develop presentation skills and the courage to address an audience was also positively acknowledged (53): There are no boundaries in the arts - you can paint a totally black picture and tell such an amazing story about it that people would be willing to pay several thousands for it. Of course, in order to tell such a convincing story, one needs the help of a teacher of literature (G8). In speaking we discover ideas, come to understand, and, of course, engage in dialogue (B9).

With regard to cognitive development, opportunities to develop their creativity (239) and imagination (201) were evaluated most positively: Literature is really inspiring (G8). Music gives rise to passion (G8). They also provide an opportunity to develop ability in maths (G9). They help people to see and describe the world in a more beautiful way, using their imagination, and every painting can have a different influence as every individual sees it in a different way (B8). The development of motor skills was also considered important in art education (97). You express your ideas using only your hands, so no words are needed. That is the essence of art (G9). Drawing in art lessons has greatly improved my handwriting (G8). The development of elementary drawing skills was also considered necessary (69): Everyone should be able to draw a little (G8). It is also thought to develop spatial intelligence (35): Art education also develops spatial thinking skills and would help you build things in the future. And if there were no art lessons, learning at school would be boring and tedious. I could not even design a garden shed, let alone a, house, in the future without studying art at school (G9). Students also think that art subjects have the capacity to develop their thinking skills (72): Literature lessons are necessary for creating a picture of the world's diversity; to be more precise, these lessons are necessary to develop children's skills to "think outside the box" and be able to change the world. I at least have such intentions and plans (G8). I can understand other people's opinions and I can also relate to their way of expressing ideas (B8).

Students' opinions about the potential contribution of art subjects to their affective development were rather diverse. They often mentioned art subjects as mental breaks between other subject lessons (107). You do not have to think about some complicated problems in these lessons all the time; you have the opportunity to relax a bit and express yourself by making music, painting or writing (G8). Creative subjects reduce stress, boredom and depression, they help you get out of the "rat race", rest and refresh your brain (G9). These subjects motivate me to come to school, because in these lessons I can be what I really am. (G9). Additional math, English, and other "valuable" subjects should not be added to our timetable at the expense of art subjects. This might make us smart subordinates, but it would fail to develop our individual creative self- 
consciousness (G9). Young people, who study so many sciences today, must also be taught Estonian culture, especially for the sake of our future (B9).

Students often cited a need to have a break from other, more difficult subjects (47). I like music lessons especially, as they give me some rest from ordinary school subjects and the whole school day; it is an enjoyable lesson, where everything is not regulated and there is also some space for creativity and my own thoughts. It can greatly support and balance an individual's mental health; it can calm you down; everybody needs to listen to soothing sounds and beautiful melodies, such as native or folk music (B8). Music gives me a place I can disappear into, away from the world (G9).

The calming, soothing effect of these lessons was mentioned quite often (43). Art, music, and literature help to reduce tensions and stress. Although I am not very good at these subjects, I still like these lessons; they are worthwhile and peaceful (B8). This lesson is very important to me, as I can think about my own ideas and problems in peace and tranquillity (G8). It is much easier after an art subject to be creative and open in the following lessons; in art lessons I always feel stress-free, and I can easily focus on drawing (B8). Several students cited the opportunity to express their feelings through drawing (71). I have learnt to express my feelings in art lessons by drawing, because it is much easier for me to express something without words (G9) I think these lessons have been included in the curricula with a specific aim: not all people should be turned into robots programmed with some prescribed amount of knowledge by the time they finish school; there should be some who can create something. That is the only way mankind can develop (G8).

Students' recognition of opportunities to broaden their horizons is usually related to increasing their knowledge of specific art subjects. With regard to new knowledge about particular subjects, the students often cited the opportunity to learn about the musical culture of other countries (86), Estonian music (68), and the history and theory of music (53). Some noteworthy quotes: Any self-respecting individual must know music and the theory of music (G7), we should know how to write music (52); I am now able to write my own melodies (G8). We also learn how to write music, which includes several mathematical operations and greatly supports the development of logical thinking skills (B8). Several students (41) mentioned the importance of learning to play different instruments: Playing different instruments helps me to keep my emotional balance (B9).

With regard to literature, the respondents highlighted the development of reading skills (141). Books have helped me to notice problems between people, and with their help I have been able to recognize several such cases in my own life; thanks to books I have a better understanding of how to solve some problems (G8). The students also mentioned the development of their writing 
skills, especially those needed to write different kinds of texts (106): One has to do many kinds of writing in one's life and we learn how to do that in literature lessons (B7). The importance of developing one's vocabulary was considered meaningful (90): If I had a poor vocabulary, nobody would listen to me, because my talk would be boring (B8); as was increasing one's motivation to read (87): When reading passages from our literature textbook, I always find many new books that are worth reading, so reading has become one of my favourite ways of relaxing. Therefore, literature lessons are necessary for developing children's interest in reading and writing (G8).

A number of students mentioned the opportunity to study the history of culture and literature (127). ...we learn about different cultures so we will not embarrass ourselves in future situations (G8). One can learn about real life through other peoples' writings, such as how they lived in earlier times (B8). Knowledge of art history was also considered useful (104): Art is really important for developing manual dexterity, but one should also know about how art has developed. Art history is so ancient and full of amazing facts, and it is interesting to learn about them (B9). Knowledge of famous artists and their most outstanding work was given separate mention as an argument in favour of having art lessons in the timetable (67); several students mentioned the need to know something about the art culture of different countries (55): We need the arts to be able to truly see the world (G8).

Although the second basic criterion (art subjects are not necessary) was only supported by $4.6 \%$ of all respondents, we think that their opinions deserve attention. Their main argument against learning art subjects is that they will not be necessary in their future lives (9). In my opinion they will not give me much for my future, at least not as much as math and other sciences, because in science lessons we must use our thinking skills and logic so that it will be easier to find a job or attend university (B9). Lessons in music and literature could be replaced by free time for those who never intend to pursue them. These lessons should be for those who are already good at them and who usually study them individually (G9). Art and music make no sense; the students could go to some music or art school (G8). Literature does not give us anything in particular it's just a bunch of thick and boring books (G8).

The issue of evaluating students' performance in art subjects was also raised for both basic criteria. Music and art education were mentioned most often (9): Art cannot be precisely evaluated, so there should be no marks awarded (G8). I do not like to do anything for a grade (B7). It would be unfair to give marks for singing, because not everybody has a talent for it (G8).

Particular attention should be paid to the students' comments about teachers. 68 of the respondents mentioned the role of teachers in making lessons interesting, motivating, and worthwhile: These subjects are necessary, but they 
should be taught by good teachers (B9). There's no need for literature, and I do not understand what the music teacher says (B7). These subjects could be optional, because some teachers are just not suitable, but everything depends on the teacher (G8). The teacher usually delivers a monologue, and nobody wants to discuss anything because the teacher immediately questions your opinion and makes you feel worthless (G8). Whether or not the lessons are interesting depends on the teacher's attitude; actually, everything depends on her (B9). I do not like music lessons because they are no fun; we must just fill in worksheets or write in copybooks as the teacher tells us, and we don't know how to do it (B7). We should not be awarded grades in these lessons; teachers often give marks according to their personal likes and dislikes (G8).

The results of the analysis have to be regarded as the subjective opinions and judgements of the respondents and cannot be generalised too widely. Yet, they provide grounds for preliminary conclusions and reveal clear tendencies in students' way of thinking and understanding the national curriculum policies expressed in their school timetables.

\section{Conclusions}

Arts subjects have always had a solid place in the National Curricula of Estonia and this necessity was supported also by pupils' opinions in this research. Generalizing the results of the present research it can be noticed that the majority of the respondents $(95,4 \%)$ supported the place of arts subjects in the curriculum and their answers revealed that these subjects were understood to support cognitive, affective and personality development as well as the development of social skills.

Accordingly, the results of the present study do not support the idea of some educational policy makers, who, led only by attempts to "optimize" educational costs, have proposed without any serious argumentation, to consider the possibility of reducing the importance and number of lessons dedicated to learning different arts. On the contrary, recent research in neurosciences has also revealed positive effects on child brain development (Huotilainen, Putkinen, \& Tervaniemi, 2009; Brattico \& Pearce, 2013). According to Gruhn, any active experience "engraves traces in the brain" (Gruhn 2011, p. 362), affecting and forming the structure plasticity of the brain, shaping the individual structure of it, according to the challenges to which it is exposed. He also stresses the importance of sequential learning "which has to be a developmental process in which earlier experiences provide the foundation for making sense to later ones" (Mercer, 1995; cited by Gruhn, 2011, p. 366).

The research on art subjects in national curricula from students' perspective has revealed interesting results and given grounds for further discussion. 
Education, including music education is a moral enterprise beyond all other devices of human origin that can balance unpredictable developmental events of post-modern times providing support for cohesion in society (Sepp 2014, p. 63). Thus, the political idea of decreasing the role of art subjects in curricula for general comprehensive schools seems short-sighted and disadvantageous considering the development of all the generations to come, able to preserve and enrich our culture and cohesion in society.

\section{References}

Aaviksoo, J. (2013). Kas Eesti kool on huvitav? (Is Estonian school interesting?) Õpetajate Leht, 23.08. http://opleht.ee/7940-jaak-aaviksoo-kas-eesti-kool-on-huvitav/

Autio, T. (2015). The Enlightenment was a Huge Pedagogical Project: Reconsidering the legacies of Anglo-American Curriculum, North-European Bildung and Chinese Wisdom Traditions amidst the Current Economic, Educational and Social Crisis. European Journal of Curriculum Studies Vol. 2, No. 1, pp. 182-190.

Benavot, A., Cha, Y. K. et al. (1991). Knowledge for the Masses: World Models and National Curricula 1920-1986. American Sociological Review, Vol. 56, No. 1, pp. 85-100.

Brattico, E., \& Pearce, M. (2013). The neuroaesthetics of music. Psychology of Aesthetics, Creativity and the Arts, Vol 7 (1), pp. 48-61.

Cohen, L., Manion, L., \& Morrison, K. (2007). Research Methods in Education. London: Routledge.

Gruhn, W. (2011). Genes or Genius?: Perspectives from Neurosciences on Music Learning and Implications for Teaching Inside and Outside School. In Liimets, A. \& Mäesalu, M. (Eds.). Music Inside and Outside the School, Baltische Studien zur Erziehungs- und Sozialwissenschaft, Band 21, pp. 361-370. Frankfurt am Main: Peter Lang, Internationaler Verlag der Wissenschaften.

Hsieh, H.-F., \& Shannon, S. E. (2005). Three Approaches to Qualitative Content Analysis. Qualitative Health Research, Vol. 15, No. 9, pp. 1277-1288.

Huotilainen, M., Putkinen, V., \& Tervaniemi, M. (2009). Brain research reveals automatic musical memory functions in children. Annals of the New York Academy of Sciences, 1169, pp. 178-181.

Kalamees-Ruubel, K. (2014). The Role of Estonian and Literature in the Curricula for General Comprehensive Schools (with Instruction in Estonian) in 1917-2014. Historical-Analytical Approach. Doctoral thesis. Institute of Educational Sciences, University of Tallinn.

Kalamees-Ruubel, K., \& Laanemets, U. (2012). Teaching Literature In and Outside of the Classroom. Procedia - Social and Behavioral Sciences, No. 45, pp. 216-226. http://www.sciencedirect.com/science/journal/18770428/45/supp/C

Laanemets, U., \& Kalamees-Ruubel, K. (2014). Curriculum development: Content, context and language learning in Estonia. European Journal of Curriculum Studies, Vol. 1, No. 1 , pp. 45-51.

Rosemund, M. (2016). Propedeutics to an international comparative analysis of state-based curriculum making. Journal of Curriculum Studies, Vol. 48, No. 6, pp. 815-832. 
Salminen, J., \& Annevirta, T. (2016). Curriculum and Teachers' pedagogical Thinking When Planning for Teaching. European Journal of Curriculum Studies, Vol. 3, No.1, pp. 182190.

Sepp, A. (2014). From music syllabi to teachers' pedagogical thinking: a comparative suty of Estonian and Finnish basic school music education. Doctoral thesis. University of Helsinki.

Scott, D. (2014). Curriculum Standards: Performance and Competence. European Journal of Curriculum Studies, Vol. 1, No. 1, pp. 5-14.

Westbury, I., \& Sivesind, K. (2016a). State-based curriculum making. Part I. Journal of Curriculum Studies, Vol. 48, No. 6, pp. 744-756.

Westbury, I., \& Sivesind, K. (2016b). State-based curriculum making. Part II. Journal of Curriculum Studies, Vol. 48, No. 6, pp. 757-765.

Westbury, I., \& Sivesind, K. (2016c). State-based curriculum work and curriculum making: Norway's Lereplanwerket 1997. Journal of Curriculum Studies, Vol. 48, No. 6, pp. $766-782$.

Westbury, I. (2016d). State-based curriculum making: the Illinois learning Standards. Journal of Curriculum Studies, Vol. 48, No. 6, pp. 783- 802. 